\title{
Weed Control in Young Coffee Plantations Through Post-Emergence Herbicide Application onto Total ARea ${ }^{1}$
}

\author{
Controle de Plantas Daninhas em Cafezais Recém-Implantados, com Herbicidas Aplicados em \\ Pós-Emergência em Área Total
}

RONCHI, C.P. ${ }^{2}$ e SILVA, A.A. ${ }^{3}$

\begin{abstract}
This study was carried out to investigate the efficiency of several herbicides under field conditions, by post-emergence application onto the entire area, their effect on the control of weeds in young coffee plantations and commercial coffee and bean intercropping system, as well as on both crops. Seedlings of Coffea arabica cv. Red Catuaí with four to six leaf pairs were transplanted to the field and treated according to conventional agronomic practices. A bean and coffee intercropping system was established by sowing three lines of beans in the coffee inter-rows. At the time the herbicides were sprayed, the coffee plants had six to ten leaf pairs; the bean plants, three leaflets; and the weeds were at an early development stage. Fluazifop-p-butyl and clethodim were selective for coffee plants and controlled only Brachiaria plantaginea and Digitaria horizontalis efficiently. Broad-leaved weeds (Amaranthus retroflexus, Bidens pilosa, Coronopus didymus, Emilia sonchifolia, Galinsoga parviflora, Ipomoea grandifolia, Lepidium virginicum, and Raphanus raphanistrum) were controlled with high efficiency by sole applications of fomesafen, flazasulfuron, and oxyfluorfen, except $B$. pilosa, C. didymus, and R. raphanistrum for oxyfluorfen. Sequential applications in sevenday intervals of fomesafen + fluazifop-p-butyl, or clethodim, and two commercial mixtures of fomesafen + fluazifop-p-butyl simultaneously controlled both types of weed. Cyperus rotundus was only controlled by flazasulfuron. Except for fluazifop-p-butyl and clethodim, all herbicide treatments caused only slight injuries on younger coffee leaves. However, further plant growth was not impaired and coffee plant height and stem diameter were therefore similar in the treatments, as evaluated four months later. Fomesafen, fluazifopp-butyl, and clethodim, at sole or sequential application, and the commercial mixtures of fomesafen + fluazifop-p-butyl were also highly selective for bean crop; thus at doses recommended for bean crop, these herbicides may be applied to control weeds in coffee and bean intercropping systems by spraying the entire area.
\end{abstract}

Key words: Coffea arabica, Phaseolus vulgaris, intercropping, selectivity.

RESUMO - Este trabalho foi realizado com o objetivo de investigar, em campo, a eficiência de vários herbicidas aplicados em pós-emergência em área total no controle de plantas daninhas, em cafezais recém-implantados e no consórcio de café e feijão, assim como seus efeitos sobre essas culturas. Mudas de Coffea arabica, cultivar Catuai Vermelho, com quatro a seis pares de folhas foram transplantadas para o campo e cultivadas segundo práticas agronômicas usuais. O consórcio de café e feijão foi obtido por meio do plantio de três linhas de feijão nas entrelinhas do cafezal. Quando os herbicidas foram aplicados sobre as culturas, as plantas de café estavam com seis a dez pares de folhas, as de feijão com três foliolos e as plantas daninhas no estádio inicial de desenvolvimento. Fluazifop-p-butil e clethodim foram seletivos às plantas de café e controlaram eficientemente Brachiaria plantaginea e Digitaria horizontalis. Plantas daninhas dicotiledôneas (Amaranthus retroflexus, Bidens pilosa, Coronopus didymus, Emilia sonchifolia, Galinsoga parviflora, Ipomoea grandifolia, Lepidium virginicum $e$ Raphanus raphanistrum) foram controladas eficientemente por aplicações isoladas de fomesafen,

Recebido para publicação em 30.8.2004 e na forma revisada em 17.12.2004.

Doutorando, Departamento de Fisiologia Vegetal da Universidade Federal de Viçosa - UFV, 36570-000 Viçosa-MG, $<$ ronchicp@yahoo.com.br>; ${ }^{3}$ Professor, Departamento de Fitotecnia - UFV. 


\begin{abstract}
flazasulfuron e oxyfluorfen, com exceção de B. pilosa, C. didymus e R. raphanistrum para o oxyfluorfen. Aplicações seqüenciais com intervalos de sete dias de fomesafen + fluazifop-p-butil ou clethodim, e as duas misturas comerciais de fomesafen + fluazifop-p-butil controlaram simultaneamente ambos os tipos de plantas daninhas. Cyperus rotundus foi controlada apenas por flazasulfuron. Com exceção de fluazifop-p-butil e clethodim todos os demais tratamentos herbicidas provocaram apenas leves injúrias às folhas mais novas das plantas de café. Contudo, o crescimento das plantas não foi prejudicado, de forma que tanto a altura como o diâmetro do caule do cafeeiro foram os mesmos entre tratamentos, em avaliações realizadas quatro meses após suas aplicações. Fomesafen, fluazifop-p-butil e clethodim, em aplicações isoladas ou seqüenciais, e as misturas comerciais de fomesafen + fluazifop-p-butil foram também seletivos para a cultura do feijão, podendo, portanto, nas doses recomendadas para esta cultura, ser usadas para controle de plantas daninhas no consórcio de café e feijão, em aplicação em área total.
\end{abstract}

Palavras-chave: $\quad$ Coffea arabica, Phaseolus vulgaris, consórcio, seletividade.

\section{INTRODUCTION}

Coffee, principally Coffea arabica, is the most important crop in Brazil on account of the expressive earnings and employment it generates (Embrapa, 2004). In addition, Brazil ranks first in world coffee production and exportation. Nowadays, a cultivated area of 2,338 million hectares with 5,387 billion coffee plants, and a production of 2,297 billion tons in 2004/2005 (Conab, 2004) are estimated. Owing to weed competition, coffee yield and quality drop drastically, and weeding entails high costs as one of the major cultural operations. Different intensities of crop yield losses caused by weed competition have been observed: 77\% (Blanco et al., 1982); 55\% (Oliveira et al., 1979), 65\% (Eshetu, 2001), 52\% (Pereira \& Jones, 1954), 28\% (Merino et al., 1996) and 24\% (Moraima, et al., 2000). In addition to coffee yield losses, several other harmful effects of weed competition on the crop have been discussed in other studies (Friessleben et al., 1991; Njoroge, 1994; Toledo et al., 1996; Ronchi, 2002; Silva \& Ronchi, 2003), including the greater competitive potential for nutrients weeds have, compared to coffee (Gallo et al., 1958; Ronchi et al., 2003).

As observed in over two-year-old coffee plantations during the drought period (from October to April, according to Blanco et al., 1982), young coffee plants, after transplanting, are very sensitive to weed interference in the coffee row, so crop growth and reproductive life may be affected if there is no weed control within appropriate time. In up to two-year-old coffee plantations, weed management should keep coffee rows free of any harmful weeds. This can be done by monthly hand-hoeing, through a selective herbicide applied in preor post-emergence of weeds, or by a carefully applied non-selective herbicide (without drift) under the coffee plant canopy (Ronchi et al., 2001). However, handling weeds in/within the coffee rows at this stage is delicate. In addition to the high costs, hand-hoeing control is not always possible, due to labour shortage or excessive soil humidity. Chemical control, on the other hand, offers whether a selective herbicide to be applied over the plant tops just after transplanting, or the appropriate technology for non-selective herbicide application under the canopy of the young coffee plants (Ronchi et al., 2001; Rodrigues et al., 2003).

In coffee plantations up to about two years from planting in the field and also in stumped coffee, mainly with wide inter-rows, the intercropping system is commonly used by farmers. By inserting an economic crop in-between coffee rows, soil erosion can be reduced and the economic return per area unit raised, through the production of two crops instead of coffee only and the reduced costs in coffee production, mainly through reductions in weed management operations (Melles et al., 1985). Since the crop arrangement in the intercropping systems may hamper weed control with common mechanical methods, the chemical control of weeds becomes all the more important. However, differences among crops in the intercropping system make the use of herbicides complicated, because different plants may have different selectivity 
mechanisms to herbicides (Silva \& Silva, 1984). Therefore, the herbicide must be simultaneously selective for both intercrop species, or its application precisely addressed to at least one of the crops (Silva \& Silva, 1984).

Although several herbicides are registered for the use in coffee plantations (Rodrigues $\&$ Almeida, 1998), only few of them are selective enough to be applied directly over the crop, at post-emergence of weeds (Alcântara, 2000a; Alcântara, 2000b; Oliveira \& Begazo, 1989). Currently, few studies are engaged in investigating or selecting among all registered those herbicides commonly used for different crops, with a potential to be used in young coffee plantations, in total area application. In our previous study (Ronchi \& Silva, 2003), conducted with young pot-grown $C$. arabica under greenhouse conditions, it was observed that herbicides like fluazifop-p-butyl, clethodim, fomesafen, and fluazifop-p-butyl + fomesafen showed a great potential for postemergence application on plant tops, since they neither injured the plants nor affected the dry matter yield significantly. Thus, this study aimed at investigating the efficiency of several herbicides under field conditions, applied as total area post-emergence application, their effect on weed control in a young coffee plantation and in a commercial coffee and bean intercropping system, as well as its effect on both crops.

\section{MATERIALS AND METHODS}

This study consisted of two fieldexperiments, simultaneously conducted at two different sites and conditions, both in Viçosa $\left(20^{\circ} 45^{\prime} \mathrm{S}, 4^{\circ} 5^{\circ} \mathrm{W}\right.$; 650 masl), Minas Gerais, south-eastern Brazil.

\section{Experiment 1}

The experimental area was previously ploughed and disked twice. The soil at the site is a Cambic Yellowish Red Podzolic, terrace phase, and plantlets of Coffea arabica L. cv Red Catuai with four to six leaf pairs were transplanted, one plant per hole, spaced $1.0 \mathrm{~m} \times 1.0 \mathrm{~m}$. Preparatory fertilisation in the planting hole consisted of $13 \mathrm{~g} P$ supplied as single super phosphate, and 15 and 60 days after transplanting $7 \mathrm{~g} \mathrm{~N}$ was supplied as ammonium sulphate and $5 \mathrm{~g} \mathrm{~K}$ as $\mathrm{KCl}$. The soil was maintained approximately at field capacity by periodic irrigations.

The experiment was established in a randomised complete block design, with four replications. The plot size was five rows of $5 \mathrm{~m}$ each, with 5 plants per row (total of 25 plants), and the nine central plants per plot were considered for the evaluations. Herbicides (Table 1) were applied over the coffee plants, covering the entire plot area, 21 days after transplanting when the plants had grown six to eight leaf pairs. The herbicide was applied by a $\mathrm{CO}_{2}$ pressurised precision sprayer, at a pressure of $300 \mathrm{kPa}$ and a volume of $200 \mathrm{~L} \mathrm{ha}^{-1}$. The sprayer boom was kept at $0.5 \mathrm{~m}$ above the ground, with five TeeJet XR11003 sprayer nozzles (Spraying Systems Co.), spaced $0.5 \mathrm{~m}$, spraying a $2.5 \mathrm{~m}$ wide strip of land. The treatments were applied from 06:00 AM to 08:00 AM when the air temperature was $28{ }^{\circ} \mathrm{C}$ and relative humidity $85 \%$. Two control treatments, weeding and hand-hoeing, both without any herbicide application, were also included (Table 1). At the time of herbicide application, the main prevalent weeds in the experimental area and their density per square meter were nutgrass - 159 (Cyperus rotundus), galinsoga - 148 (Galinsoga parviflora), wild radish - 27 (Raphanus raphanistrum), beggar's ticks - 21 (Bidens pilosa), dayflower 12 (Commelina benghalensis), redroot amaranth - 12 (Amaranthus retroflexus), morningglory - 6 (Ipomoea grandifolia), brachiaria - 6 (Brachiaria plantaginea), red tasselflower - 5 (Emilia sonchifolia). All weeds were in an early development stage, with one to two leaf pairs. To keep coffee plants free of $C$. rotundus interference, which was the only weed at the site tolerant to almost all herbicides used, the whole experimental area except the weed treatment was hoed 60 and 105 days after the treatments (DAT). At this time (60 DAT), the herbicide effect on weed control had already been evaluated.

The control of weed species by herbicides was evaluated 30 DAT in percentage scores, in which zero represents absence of control and $100 \%$ represents the total weed control, using an untreated plot as reference. At this time, weeds were sampled by randomly throwing a metal square $(0.3 \mathrm{~m} \times 0.3 \mathrm{~m})$ twice 
onto each plot. All weeds within the metal square were collected, identified, and, after counting their shoots, were oven-dried for $72 \mathrm{~h}$, at $70{ }^{\circ} \mathrm{C}$ to determine the dry mass. Thirty DAT, the percentage of the plot covered by weeds was evaluated, since this also indicates the herbicide efficiency for weed control. At 30 and 130 DAT, the herbicide toxicity to coffee plants was also evaluated by percentage scores, in which zero represents absence of symptoms and 100\% represents the plant canopy's death. Plant height and stem diameter were also evaluated at 130 DAT. The data of plant height and stem diameter were subjected to ANOVA and the statistical significance of mean differences was analysed by the Tukey's test at $P<0.05$. These statistical analyses were performed using the SAEG System version 8.0 (SAEG, 1999).

\section{Experiment 2}

This experiment was established in a typical Brazilian commercial crop of Coffea arabica cv Red Catuaí, spaced 2.0 m x $1.0 \mathrm{~m}$, which had already been transplanted approximately two months earlier and was being managed according to the common agronomic practices adopted by the farmer. The soil was a Yellowish Red Podzolic, and in an attempt to standardise the weed development stage in the experimental area before the beginning of experiment, weeds were completely eliminated by hoeing. In order to establish bean (Phaseolus vulgaris) and coffee intercropping, as commonly done in commercial plantations, three rows of the former were sown in the coffee inter-rows, two seeds a hole, spaced $0.5 \mathrm{~m}$ x $0.2 \mathrm{~m}$.

The experimental design was as in Experiment 1. Every plot held three five-meter coffee rows (i.e., six rows of bean), comprising 15 and 60 coffee and bean plants, respectively. The herbicide (Table 3) was applied as in Experiment 1, although air temperature and relative humidity were $23{ }^{\circ} \mathrm{C}$ and $80 \%$, respectively. At this stage, coffee plants had eight to 10 leaf pairs, the bean plants three leaflets, and the weeds were in an early stage of development. The weeds present in the experimental area were peppergrass (Lepidium virginicum), swinecress (Coronopus didymus), wild radish (Raphanus raphanistrum), beggar's ticks (Bidens pilosa) and summer grass (Digitaria horizontalis). Among them, L. virginicum and $C$. didymus were the most abundant, comprising $38 \%$ and $37 \%$, respectively, of all weeds. Thirty-five DAT, herbicide toxicity to coffee and bean plants, weed control, and the percentage of the plot covered by weeds were evaluated. Ninety DAT, herbicide toxicity to crop, plants height, and stem diameter were also evaluated. The evaluation methods were exactly the same as previously described for Experiment 1.

Table 1 - Effect of herbicide treatments on young coffee plants in Experiment 1, evaluating herbicide toxicity, plant height, and stem diameter

\begin{tabular}{|c|c|c|c|c|c|}
\hline \multirow{2}{*}{ Treatment $^{1 /}$} & \multirow{2}{*}{$\begin{array}{c}\text { Dose }^{1} \\
\left(\mathrm{~g} \text { a.i. } \mathrm{ha}^{-1}\right) \\
\end{array}$} & \multicolumn{2}{|c|}{ Toxicity } & \multirow{2}{*}{$\begin{array}{l}\text { Plant height } t^{\frac{3}{}} \\
(\mathrm{~cm})\end{array}$} & \multirow{2}{*}{$\begin{array}{c}\begin{array}{c}\text { Stem diameter } \\
\text { (mm) }\end{array} \\
\end{array}$} \\
\hline & & Scores $(\%)$ & Grades $^{\underline{2} /}$ & & \\
\hline fomesafen $^{4 /, 12}$ & 375 & 10.0 & very slight & $23.78 \mathrm{a}$ & $4.52 \mathrm{a}$ \\
\hline fluazifop-p-buty $1^{\frac{5}{3}, 12}$ & 500 & 0.0 & none & $24.51 \mathrm{a}$ & $4.46 \mathrm{a}$ \\
\hline clethodim $^{6,13}$ & 192 & 0.0 & none & $25.18 \mathrm{a}$ & $4.74 \mathrm{a}$ \\
\hline (fluazifop-p-butyl + fomesafen) $)^{7,}, \underline{12}^{\prime}$ & $375+375$ & 18.3 & slight & $24.60 \mathrm{a}$ & $4.52 \mathrm{a}$ \\
\hline (fluazifop-p-butyl + fomesafen) $)^{8,1,12}$ & $375+300$ & 18.8 & slight & $24.67 \mathrm{a}$ & $4.32 \mathrm{a}$ \\
\hline$\left(\text { fomesafen }{ }^{4,12}+\text { fluazifop-p-butyl } 1^{5,12}\right)^{9}$ & $375+500$ & $\begin{array}{ll}31.3 \\
31.3\end{array}$ & moderate & $23.35 \mathrm{a}$ & $4.23 \mathrm{a}$ \\
\hline (fomesafen ${ }^{4 /, 12 /}+$ clethodim $\left.^{6 /, 13 /}\right)^{9 /}$ & $375+192$ & 19.3 & slight & $26.82 \mathrm{a}$ & $5.16 \mathrm{a}$ \\
\hline flazasulfuron ${ }^{10 /}$ & 50 & 25.0 & slight & $22.83 \mathrm{a}$ & $4.78 \mathrm{a}$ \\
\hline oxyfluorfen ${ }^{11}$ & 480 & 26.3 & slight & $24.30 \mathrm{a}$ & $4.37 \mathrm{a}$ \\
\hline hand-hoeing control & - & 0.0 & none & $26.57 \mathrm{a}$ & $4.91 \mathrm{a}$ \\
\hline weedy & - & 0.0 & none & $22.52 \mathrm{a}$ & $3.68 \mathrm{a}$ \\
\hline
\end{tabular}

1/ Common doses applied to annual crops according to Rodrigues \& Almeida (1998); ${ }^{2} /$ Grades of herbicide toxicity to coffee plants modified from Frans (1972); ${ }^{3 /}$ Means followed by the same small letter within each column are statistically not different $(P>0.05$, Tukey's test); ${ }^{4 /}$ Flex; ${ }^{5 /}$ Fusilade $125 ;{ }^{6 /}$ Select $240 \mathrm{CE} ;{ }^{\mathbb{1} /}$ Fusiflex; ${ }^{8 /}$ Robust; ${ }^{9 /}$ Sequential application in seven-day intervals; ${ }^{10 /}$ Katana; $\underline{11} /$ Goal; $\underline{12}, \underline{13} /$ A nonionic surfactant (Energic, $0.2 \% \mathrm{v} / \mathrm{v}$ ) and an emulsifiable mineral oil (Assist, $0.5 \% \mathrm{v} / \mathrm{v}$ ), respectively, were added to the herbicide spraying solution. 


\section{RESULTS AND DISCUSSION}

The effect of herbicide treatments on young coffee plants in Experiment 1 is presented in Table 1. As expected, the coffee plants did not show any symptoms of injury after either fluazifop-p-butyl (500 g a.i. ha ${ }^{-1}$ ) or clethodim (192 g a.i. ha-1) applications, certainly due to the high resistance of nongrass species to these herbicides (Thill, 2000). A sole application of fomesafen (375 g a.i. ha-1) over the coffee plant tops led to a very slight toxicity $(10.0 \%)$ to the crop, while after flazasulfuron (50 g a.i. ha ${ }^{-1}$ ) or oxyfluorfen (480 $\mathrm{g}$ a.i. $\mathrm{ha}^{-1}$ ) applications, the toxicity was higher, 25.0 and $26.3 \%$, respectively. When the two commercial mixtures of fluazifop-p-butyl + fomesafen $\left(375+375 \mathrm{~g}\right.$ a.i. ha $\mathrm{ha}^{-1}$ - Fusiflex or $375+300$ g a.i. ha ${ }^{-1}$ - Robust) were applied, toxicity was slight (18.8\%). A similar result was observed by sequential application of fomesafen + clethodim $\left(375+192\right.$ g a.i. ha $\left.{ }^{-1}\right)$ in seven-day intervals. However, such a sequential application of fomesafen + fluazifopp-butyl $\left(375+500 \mathrm{~g}\right.$ a.i. ha $\left.{ }^{-1}\right)$ was assessed with a moderate injury score (31.3\%). All symptoms of herbicide toxicity observed on these field-grown coffee plant leaves were the same as those previously described for pot-grown coffee plants under greenhouse conditions (Ronchi \& Silva, 2003). Although some initial toxicity, particularly on young leaves, had been observed after the herbicide application over the coffee plant tops, newly formed leaves showed no more symptoms of injury, since further evaluations did not detect herbicide toxicity (data not shown). In addition, the crop growth after herbicide application was not impaired since these treatments did not significantly $(P<0.05)$ affect the plant height and stem diameter, as evaluated three months later (Table 1).

The weed control levels according to the treatments are presented in Table 2, as percentage of control related to the weed plot, and in Table 3 as weed number and dry mass and as the percentage of weed coverage of the plot. B. plantaginea was the only grass species present in the whole experimental area and was controlled with high efficiency by any treatment containing fluazifop-p-butyl, clethodim, or flazasulfuron. By contrast, fomesafen and oxyfluorfen had no effect on that weed. All broad-leaved weeds including G. parviflora, R. raphanistrum, B. pilosa, $C$. benghalensis, A. retroflexus, I. grandifolia, and $E$. sonchifolia were also very efficiently controlled by treatments consisting in fomesafen, flazasulfuron, and oxyfluorfen, except for $C$. benghalensis and I. grandifolia, which were not controlled by flazasulfuron, and $B$. pilosa, which was quite tolerant to oxyfluorfen. There was no difference in the weed control achieved by sequential

Table 2 - Weed control 30 days after treatment application in Experiment 1

\begin{tabular}{|c|c|c|c|c|c|c|c|c|c|}
\hline \multirow[b]{2}{*}{ Treatment $^{1 /}$} & \multicolumn{9}{|c|}{ Weed control (\%) } \\
\hline & $\begin{array}{c}C . \\
\text { rotundus }\end{array}$ & $\begin{array}{c}G . \\
\text { parviflora }\end{array}$ & $\begin{array}{c}R . \\
\text { raphanistrum }\end{array}$ & $\begin{array}{c}B . \\
\text { pilosa }\end{array}$ & \begin{tabular}{|c|}
$C$. \\
benghalensis
\end{tabular} & \begin{tabular}{c|}
$A$. \\
retroflexus
\end{tabular} & \begin{tabular}{|c|} 
\\
grandifolia \\
\end{tabular} & $\begin{array}{c}B . \\
\text { plantaginea }\end{array}$ & \begin{tabular}{|c|}
$E$ \\
sonchifolia
\end{tabular} \\
\hline fomesafen $^{4 /, \underline{12} /}$ & 2.5 & 99.3 & 99.5 & 98.8 & 99.0 & 99.8 & 99.8 & 0 & 99.8 \\
\hline fluazifop-p-butyl ${ }^{5 /,} \underline{12}$ & 0 & 0 & 0 & 0 & 0 & 0 & 0 & 99 & 0 \\
\hline clethodim $^{6 /, 13}$ & 0 & 0 & 0 & 0 & 0 & 0 & 0 & 99.3 & 0 \\
\hline (fluazifop-p-butyl + fomesafen) $)^{7 /, 12}$ & 7.5 & 98.3 & 99.3 & 95.8 & 98.3 & 98.5 & 99.8 & 99 & 98.5 \\
\hline (fluazifop-p-butyl + fomesafen) $^{\frac{8}{,-12}}$ & 11.3 & 99.3 & 99.5 & 98.3 & 98.8 & 99.8 & 99.8 & 99.5 & 99.8 \\
\hline $\begin{array}{l}(\text { fomesafen } \\
\left.\text { butyl } 1^{5 /, 12 /, 12 /}+\right)^{9 /}\end{array}$ & 32.5 & 99.3 & 99.5 & 99.8 & 99.5 & 100 & 99.5 & 98.8 & 100 \\
\hline$\left(\text { fomesafen }^{4 /, 12}+\text { clethodim }^{6 /,} \underline{13}\right)^{9}$ & 11.3 & 99.5 & 99.5 & 99.3 & 96.8 & 99.5 & 99.8 & 97.3 & 99.5 \\
\hline flazasulfuron ${ }^{10}$ & 98.8 & 99.8 & 99.8 & 98.5 & 0 & 99.5 & 0 & 98.8 & 99.5 \\
\hline oxyfluorfen ${ }^{11}$ & 40 & 99 & 97.3 & 16.3 & 95.5 & 97.8 & 98 & 10 & 97.8 \\
\hline hand-hoeing control & 100 & 100 & 100 & 100 & 100 & 100 & 100 & 100 & 100 \\
\hline weedy & 0 & 0 & 0 & 0 & 0 & 0 & 0 & 0 & 0 \\
\hline
\end{tabular}

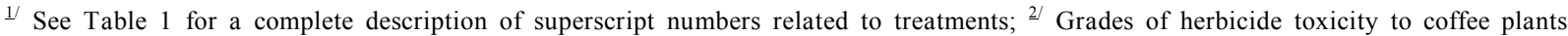
modified from Frans (1972); ${ }^{3 /}$ Means followed by the same small letter within each column are statistically not different $(P>0.05$, Tukey's test); ${ }^{4 /}$ Flex; ${ }^{5 /}$ Fusilade $125 ;{ }^{6 /}$ Select $240 \mathrm{CE} ;{ }^{7 /}$ Fusiflex; ${ }^{8 /}$ Robust; ${ }^{9 /}$ Sequential application in seven-day intervals; ${ }^{10 /}$ Katana; $\underline{11 /}$ Goal; $\frac{12 /}{13}$ A nonionic surfactant (Energic, $0.2 \% \mathrm{v} / \mathrm{v}$ ) and an emulsifiable mineral oil (Assist, $0.5 \% \mathrm{v} / \mathrm{v}$ ), respectively, were added to the herbicide spraying solution. 
Table 3 - Effect of herbicides on weed number (WNB) and dry mass (WDM) and percentage of weed coverage in the plot 30 days after treatment application in Experiment 1

\begin{tabular}{|c|c|c|c|c|c|c|c|c|c|c|c|c|c|}
\hline \multirow{3}{*}{ Treatment $^{1 /}$} & \multirow{3}{*}{$\begin{array}{l}\% \text { plot } \\
\text { coverage }\end{array}$} & \multicolumn{12}{|c|}{ Weed number (plants $\left.\mathrm{m}^{-2}\right)$ and shoot dry mass $\left(\mathrm{g} \mathrm{m}^{-2}\right)$} \\
\hline & & \multicolumn{2}{|c|}{ C. rotundus } & \multicolumn{2}{|c|}{ G. parviflora } & \multicolumn{2}{|c|}{ R. raphanistrum } & \multicolumn{2}{|c|}{ B. pilosa } & \multicolumn{2}{|c|}{ I. grandifolia } & \multicolumn{2}{|c|}{ B. plantaginea } \\
\hline & & WNB & WDM & WNB & WDM & WNB & WDM & WNB & WDM & WNB & WDM & WNB & WDM \\
\hline fomesafen ${ }^{4 /, 12 /}$ & 68.8 & 222 & 99.5 & 0 & 0 & 0 & 0 & 0 & 0 & 0 & 0 & 67 & 32.6 \\
\hline fluazifop-p-butyl ${ }^{5 /,}$ 12 & 87.5 & 165 & 110.3 & 113 & 24.8 & 6 & 8.8 & 19 & 12.6 & 11 & 10.8 & 1 & 0.9 \\
\hline clethodim $^{6,}, 13 /$ & 82.5 & 169 & 93.7 & 94 & 16.6 & 11 & 3.4 & 28 & 7.1 & 7 & 6 & 0 & 0 \\
\hline $\begin{array}{l}\text { (fluazifop-p-butyl + } \\
\text { fomesafen }^{7 /, 12 /}\end{array}$ & 50 & 226 & 95.8 & 0 & 0 & 0 & 0 & 0 & 0 & 0 & 0 & 0 & 0 \\
\hline $\begin{array}{l}\text { (fluazifop-p-butyl + } \\
\text { fomesafen }^{\frac{8}{1 / 12}}\end{array}$ & 55 & 233 & 124.2 & 0 & 0 & 0 & 0 & 0 & 0 & 0 & 0 & 0 & 0 \\
\hline $\begin{array}{l}\text { (fomesafen } \\
\left.\text { butyl }^{5 /,}, 12 /\right)^{9 /}\end{array}$ & 62.5 & 207 & 87.6 & 0 & 0 & 0 & 0 & 0 & 0 & 0 & 0 & 0 & 0 \\
\hline 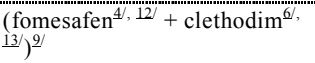 & 42.5 & 199 & 78.7 & 0 & 0 & 0 & 0 & 0 & 0 & 0 & 0 & 0 & 0 \\
\hline flazasulfuron ${ }^{10}$ & 2 & 31 & 6.2 & 0 & 0 & 0 & 0 & 0 & 0 & 6 & 6.3 & 22 & 2.6 \\
\hline oxyfluorfen $\frac{11}{11}$ & 42.5 & 238 & 78.1 & 6 & 0.9 & 6 & 1.9 & 11 & 0.4 & 0 & 0 & 46 & 43 \\
\hline hand-hoeing control & 0 & 0 & 0 & 0 & 0 & 0 & 0 & 0 & 0 & 0 & 0 & 0 & 0 \\
\hline weedy & 95 & 144 & 81.5 & 83 & 16.7 & 7 & 10.6 & 26 & 6.9 & 19 & 14.7 & 31 & 23.5 \\
\hline
\end{tabular}

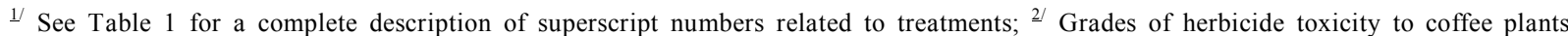
modified from Frans (1972); ${ }^{3 /}$ Means followed by the same small letter within each column are statistically not different $(P>0.05$, Tukey's test); ${ }^{4 /}$ Flex; ${ }^{5 /}$ Fusilade $125 ;{ }^{6 /}$ Select $240 \mathrm{CE} ;{ }^{7 /}$ Fusiflex; ${ }^{8 /}$ Robust; ${ }^{9 /}$ Sequential application in seven-day intervals; ${ }^{10 /}$ Katana; $\underline{11 /}$ Goal; $\underline{12} /, \underline{13} /$ A nonionic surfactant (Energic, $0.2 \% \mathrm{v} / \mathrm{v}$ ) and an emulsifiable mineral oil (Assist, $0.5 \% \mathrm{v} / \mathrm{v}$ ), respectively, were added to the herbicide spraying solution.

application in intervals of seven days of fomesafen + fluazifop-p-butyl or clethodim and the sole application of a commercial mixture of fluazifop-p-butyl + fomesafen, probably because all weeds were in an early development stage. Nevertheless, sequential applications were tested in an attempt to control first the broad-leaf and later the grass weeds. By this type of sequential application, it could be possible to achieve higher control levels of grass species (with clethodim or fluazifop-p-butyl), since their shoots could have become more exposed after the death of broad-leaved weeds by earlier fomesafen application.

As mentioned before, the experimental area was highly infested by $C$. rotundus, (Table 3) with over 150 plants $\mathrm{m}^{-2}$, so the percentage of the plot covered by weeds was $95 \%$ in the weed treatment (without weed control). Since the herbicides employed (except flazasulfuron) had little or no effect on C. rotundus (Table 2), the percentage of the plot covered by weeds remained pretty high, even after herbicide treatments that controlled almost a $100 \%$ of the broad-leaved and grass weed species. Among all herbicides, flazasulfuron was the only one that controlled $98 \%$ of $C$. rotundus
(Table 2). Moreover, the number and shoot dry mass per square meter of $C$. rotundus were reduced by 79 and $93 \%$, respectively, compared to the weed treatment, so 30 DAT the percentage of the plot covered by weeds was only $2 \%$ (Table 3 ). The weed coverage percentage was reduced by $11 \%$ (from 95 to about $85 \%$ ) after grass control by fluazifop-pbutyl or clethodim, by $28 \%$ (from 95 to $68.8 \%$ ) after broad-leaved weed control by fomesafen; and by $48 \%$ (from 95 to about $52.5 \%$ ) when both weed types were simultaneously controlled by the mixture of those herbicides, by a sole or sequential applications (Table 3).

The weed interference observed in the weed treatment reduced coffee plant height and stem diameter by 15 and $25 \%$, respectively, compared to the hand-hoeing control, which was kept weed-free; however, there was no significant statistical difference in weed interference among treatments (Table 1). After herbicide treatments which controlled all weeds except $C$. rotundus, these values dropped to an average of eight and seven percent, respectively. Probably, this explains the reduction in coffee height and stem diameter in consequence of only $C$. rotundus interference. 


\section{Experiment 2}

In experiment 2, the same treatments with lower doses of some herbicides were applied to the coffee and bean intercropping system, over the top of both crops. The initial toxicity to coffee plants was very slight (Table 4), similar to that observed in the plants of Experiment 1, and no injury symptoms were observed in further evaluations. Moreover, neither coffee plant height nor stem diameter were affected by the treatments, as evaluated 90 DAT (data not shown).

Fomesafen, fluazifop-p-butyl, clethodim, two commercial mixtures of fluazifop-pbutyl + fomesafen, and sequential applications of fomesafen + fluazifop-p-butyl or clethodim were highly selective for bean plants, so no injury symptoms were observed (Table 4). Such a result had been expected since these herbicides are registered and commonly recommended for weed control in bean (Rodrigues \& Almeida, 1998). Flazasulfuron and oxyfluorfen killed all bean plants (Table 4). A sole application of fomesafen was very efficient for the control of broad-leaved weeds (C. didymus, L. virginicum, $R$. raphanistrum and B. pilosa), while a sole application of fluazifopp-butyl or clethodim efficiently controlled $D$. horizontalis. Since broad-leaved weeds, particularly $L$. virginicum and $C$. didymus, were the predominant species in the experimental area of Experiment 2, the percentage of the plot covered by weeds remained higher, 37.5 and $50.0 \%$, after fluazifop-p-butyl or clethodim application, respectively, and much lower (2\%) after fomesafen application, as compared to $65 \%$ of the weed plot (Table 5 ). When the commercial mixture or sequential application of these herbicides were applied, the weeds were almost completely controlled, reducing the percentage of the plot covered by weeds, compared to the weed treatment (Table 5).

On the grounds of the present experiment, conducted under two different field conditions, it was observed that the sole application of fomesafen, fluazifop-p-butyl, and chethodim, the sequential application of fomesafen plus fluazifop-p-butyl or clethodim, and the application of commercial mixtures of fomesafen + fluazifop-p-butyl were selective for young transplanted coffee plants, although some initial symptoms of injury were observed. At doses recommended to the bean crop, these herbicides may therefore be applied for the control of weeds in the coffee bean intercrop system, by spraying of the entire area. Broad-leaved weeds were efficiently controlled by sole applications of fomesafen, flazasulfuron, and oxyfluorfen, grass species by fluazifop-p-butyl or clethodim, while both weed types were simultaneously controlled by any employed treatment with both fomesafen and fluazifop-p-butyl or clethodim. Only flazasulfuron was efficient for the control of $C$. rotundus.

Table 4 - Herbicide toxicity for inter-cropped young coffee and bean plants in Experiment 2

\begin{tabular}{|c|c|c|c|c|c|}
\hline \multirow{2}{*}{ Treatment $^{1 /}$} & \multirow{2}{*}{$\begin{array}{c}\text { Dose } \\
\left(\mathrm{g} \mathrm{a.i.}^{-1}\right)\end{array}$} & \multicolumn{2}{|c|}{ Coffee plants } & \multicolumn{2}{|c|}{ Bean plants } \\
\hline & & $\%$ & $\mathrm{Grade}^{2 /}$ & $\%$ & $\mathrm{Grade}^{2 /}$ \\
\hline fomesafen $^{4 /, 12 /}$ & 250 & 10 & very slight & 0 & none \\
\hline fluazifop-p-butyl $1^{5 /, 12 /}$ & 375 & 0 & none & 0 & none \\
\hline clethodim ${ }^{6},, \underline{13}$ & 120 & 0 & none & 0 & none \\
\hline (fluazifop-p-butyl + fomesafen) ${ }^{\mathrm{Z},}, \underline{12}$ & $250+250$ & 11.3 & very slight & 0 & none \\
\hline (fluazifop-p-butyl + fomesafen) ${ }^{\underline{8}, \underline{12}}$ & $250+200$ & 17.5 & very slight & 0 & none \\
\hline 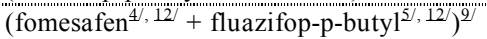 & $250+375$ & 9.5 & very slight & 0 & none \\
\hline 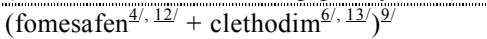 & $250+120$ & 8.8 & very slight & 0 & none \\
\hline flazasulfuron ${ }^{10 /}$ & 50 & 9.5 & very slight & 100 & death \\
\hline oxyfluorfen ${ }^{11}$ & 480 & 16.3 & slight & 100 & death \\
\hline hand-hoeing control & - & 0 & none & 0 & none \\
\hline weedy & -"- & 0 & none & 0 & none \\
\hline
\end{tabular}

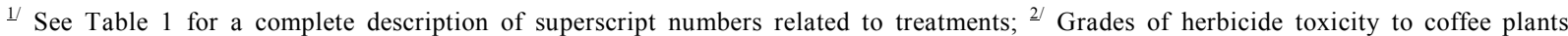
modified from Frans (1972); ${ }^{3 /}$ Means followed by the same small letter within each column are statistically not different $(P>0.05$, Tukey's test); ${ }^{4 /}$ Flex; ${ }^{5 /}$ Fusilade $125 ;{ }^{6 /}$ Select $240 \mathrm{CE} ;{ }^{7 /}$ Fusiflex; $\stackrel{8 /}{\text { Robust; }}{ }^{9 /}$ Sequential application in seven-day intervals; ${ }^{10 /}$ Katana; $11 /$ Goal; $\frac{12 /}{13}$ A nonionic surfactant (Energic, $0.2 \% \mathrm{v} / \mathrm{v}$ ) and an emulsifiable mineral oil (Assist, $0.5 \% \mathrm{v} / \mathrm{v}$ ), respectively, were added to the herbicide spraying solution. 
Table 5 - Percentage of weed coverage in the plot and weed control 35 days after treatment application in Experiment 2

\begin{tabular}{|c|c|c|c|c|c|c|}
\hline \multirow{2}{*}{ Treatment $\mathrm{t}^{1 /}$} & \multirow{2}{*}{$\begin{array}{c}\% \text { plot } \\
\text { coverage }\end{array}$} & \multicolumn{5}{|c|}{ Weed control $(\%)$} \\
\hline & & L. virginicum & C. didymus & R. raphanistrum & B. pilosa & D. horizontalis \\
\hline fomesafen $n^{4 /, 12}$ & 2 & 99.8 & 99.8 & 99.5 & 100 & 0 \\
\hline fluazifop-p-butyl ${ }^{\mathrm{5} /, \underline{12}}$ & 37.5 & 0 & 0 & 0 & 0 & 100 \\
\hline clethodim $^{6}, \underline{13}$ & 50 & 0 & 0 & 0 & 0 & 100 \\
\hline (fluazifop-p-butyl + fomesafen $)^{\frac{7}{,}, \underline{12}}$ & 0.6 & 98.3 & 99 & 100 & 100 & 100 \\
\hline (fluazifop-p-butyl + fomesafen $)^{8 / 12}$ & 1.25 & 97 & 98.5 & 100 & 98.8 & 98.8 \\
\hline$\left(\text { fomesafen }{ }^{4 /, 12}+\text { fluazifop-p-butyl }{ }^{5 /,} \underline{12}\right)^{9 /}$ & 2.1 & 99.5 & 99.5 & 98.8 & 100 & 100 \\
\hline$\left(\text { fomesafen }{ }^{4 /, 12}+\text { clethodim }^{6 /, 13}\right)^{9}$ & 3.63 & 97 & 98.8 & 100 & 100 & 100 \\
\hline flazasulfuron ${ }^{10}$ - & 1.3 & 99.8 & 99.8 & 95.8 & 80.8 & 100 \\
\hline oxyfluorfen 11 & (n) & (n) & 90.8 & 72.5 & 18.5 & (n) \\
\hline hand-hoeing control & 0 & 100 & 100 & 100 & 100 & 100 \\
\hline weedy & 65 & 0 & 0 & 0 & 0 & 0 \\
\hline
\end{tabular}

1/ See Table 1 for a complete description of superscript numbers related to treatments; $\stackrel{2}{2}$ Grades of herbicide toxicity to coffee plants modified from Frans (1972); ${ }^{\underline{3} /}$ Means followed by the same small letter within each column are statistically not different $(P>0.05$, Tukey's test); ${ }^{4 /}$ Flex; ${ }^{5 /}$ Fusilade $125 ;{ }^{6}$ Select $240 \mathrm{CE} ;{ }^{7 /}$ Fusiflex; ${ }^{8 /}$ Robust; ${ }^{2}$ Sequential application in seven-day intervals; ${ }^{10 /}$ Katana; $\underline{11 /}$ Goal; $\underline{12} / \underline{13 /}$ A nonionic surfactant (Energic, $0.2 \% \mathrm{v} / \mathrm{v}$ ) and an emulsifiable mineral oil (Assist, $0.5 \% \mathrm{v} / \mathrm{v}$ ), respectively, were added to the herbicide spraying solution.

\section{LITERATURE CITED}

ALCÂNTARA, E. N. Avaliação de herbicidas para cafeeiros em formação. In: CONGRESSO BRASILEIRO DA CIÊNCIA DAS PLANTAS DANINHAS, v. 22, 2000, Foz do Iguaçu. Resumos... Londrina: SBCPD, 2000a. p. 344.

ALCÂNTARA, E. N. Avaliação de herbicidas para cafeeiros em formação. In: SIMPÓSIO DE PESQUISA DOS CAFÉS DO BRASIL, 1., 2000, Poços de Caldas. Resumos

Expandidos... Brasília, DF: Embrapa Café, 2000b. p. $967-970$.

BLANCO, H. G.; OLIVEIRA, D. A.; PUPO, E. I. H. Período de competição de uma comunidade natural de mato em uma cultura de café em formação. Biológico, v. 48, p. 9-20, 1982.

\section{COMPANHIA NACIONAL DE ABASTECIMENTO -}

CONAB. Segunda previsão (Abril/04) da safra brasileira de café 2004/2005 e levantamento do parque cafeeiro nacional. Disponível em: <http://www.conab.gov.br/download/Safra/ Safracafe.pdf $>$. Acesso em: 25 jul. 2004.

\section{EMPRESA BRASILEIRA DE PESQUISA} AGROPECUÁRIA - EMBRAPA. Café: histórico. Disponível em: $<$ http://www.embrapa.br/cafe/ historico.htm>. Acesso em: 29 fev. 2004.

ESHETU, T. Weed flora and weed control practices in coffee. In: COLLOQUE SCIENTIFIQUE

INTERNATIONAL SUR LE CAFÉ, 19., 2001, Trieste. Colloque... Paris: ASIC, 2001. p. 1-9.
FRANS, R. E. Measuring plant response. In: WILKINSON, R. E. (Ed.). Research methods in weed science. [S.1.]: Southern Weed Science Society, 1972. p. $28-41$.

FRIESSLEBEN, U.; POHLAN, J.; FRANKI, G. The response of Coffea arabica L. to weed competition. Café, Cacao The, v. 35, p. 15-20, 1991.

GALLO, J. R. et al. Absorção de nutrientes pelas ervas daninhas e sua competição com o cafeeiro. Bol. Inst. Agron., v. 104, 1958. 13 p.

MELLES, C. C. A. et al. Culturas intercalares em lavouras cafeeiras nas fases de formação e produção. Inf. Agropec., v. 11, n. 126, p. 65-68, 1985.

MERINO, M. C. I.; RAMIRES, A. R.; IBARRA, E. L. Study on critical periods for interspecific competition, weeds-coffee. In: SIMPOSIO SOBRE CAFEICULTURA LATINOAMERICANA, 17., 1996, San Salvador. Resumem... Tegucigalpa: IICA, 1996. 15 p.

MORAIMA, G. S. et al. A contribution to determine critical levels of weed interference in coffee crops of Monagas state, Venezuela. Bioagro, v. 12, p. 63-70, 2000.

NJOROGE, J. M. Weeds and weed control in coffee. Exp. Agric., v. 30, p. 421-429, 1994.

OLIVEIRA, J. A.; BEGAZO, J. C. E. Utilização de herbicidas pré-emergentes na cultura do café em formação (Coffea arabica L.). Cafeicult. Moderna, v. 2, n. 6. p. 20-25, 1989 . 
OLIVEIRA, J. A.; MATIELO, J. B.; CARVALHO, F.

Estudo do efeito da época de controle das plantas daninhas em café. In: CONGRESSO BRASILEIRO DE PESQUISA CAFEEIRA, 7., 1979, Araxá. Resumos... Rio de Janeiro: IBC, 1979. p. 360-362.

PEREIRA, H. C.; JONES, P. A. A tillage study in Kenya Coffee. Part I: The effects of tillage practices on coffee yields. Emp. J. Exp. Agric., v. 22, p. 231-240, 1954.

RODRIGUES, B. N.; ALMEIDA, F. S. Guia de herbicidas. 4.ed. Londrina: 1998. 648 p.

RODRIGUES, G. J. et al. Eficiência de uma barra de pulverização para aplicação de herbicida em lavouras de café em formação. Planta Daninha, v. 21, n. 3, p. 459-465, 2003.

RONCHI, C. P. Interferência e controle de plantas daninhas na cultura de café (Coffea arabica L.). 2002.

115 f. Dissertação (Mestrado em Fitotecnia) - Universidade Federal de Viçosa, Viçosa, 2002.

RONCHI, C. P.; SILVA, A. A. Tolerância de mudas de café a herbicidas aplicados em pós-emergência. Planta Daninha, v. 21, n. 3, p. 421-426, 2003.
RONCHI, C. P.; SILVA, A. A.; FERREIRA, L. R. Manejo de plantas daninhas em lavouras de café. Viçosa: Universidade Federal de Viçosa. 2001. 94 p.

RONCHI, C. P. Acúmulo de nutrientes pelo cafeeiro sob interferência de plantas daninhas. Planta Daninha, v. 21, n. 2, p. 219-227, 2003.

SILVA, A. A.; RONCHI, C. P. Avanços nas pesquisas sobre o controle de plantas daninhas na cultura do café. In: ZAMBOLIM L (Ed.) Produção integrada de café. Viçosa: UFV/DFP, 2003. p. 103-132.

SILVA, J. F.; SILVA, N. G. Controle de plantas daninhas em feijão (Phaseolus vulgaris L.) consorciado com outras culturas. Inf. Agropec., v. 10, n. 118, p. 70-74, 1984.

SISTEMA PARA ANÁLISES ESTATÍSTICAS - SAEG, v. 8.0. Viçosa, MG: Fundação Arthur Bernardes, 1999.

THILL, D. Lipid biosynthesis inhibitors: group one. In: Herbicide Action Course, Part A. West Laffayett: Purdue University, 2000. p. 306-333.

TOLEDO, S. V.; MORAES, M. V.; BARROS, I. Efeito da freqüência de capinas na produção do cafeeiro. Bragantia, v. 55, p. 317-324, 1996. 